Review

\title{
Smart Agriculture: The Future of Agriculture using AI and IoT
}

\author{
${ }^{1}$ Sapna Katiyar and ${ }^{2}$ Artika Farhana \\ ${ }^{1}$ Department of Electronics and Communication Engineering, ABES Institute of Technology, Ghaziabad, India \\ ${ }^{2}$ Department of Computer Science, Jizan University, Saudi Arabia
}

\author{
Article history \\ Received: 18-09-2021 \\ Revised: 12-10-2021 \\ Accepted: 15-10-2021 \\ Corresponding Author: \\ Artika Farhana \\ Department of Computer \\ Science, Jizan University, Saudi \\ Arabia \\ Email: far1984hana@gmail.com
}

\begin{abstract}
Agriculture sector contributing a significant share in World economy and in more than nine counties agronomy is the leading segment. Population is rising immensely therefore quality and quantity of food demand increases enormously. Agriculture segment is providing employment prospects to large population as well. Conventional farming styles used by farmers are not competent to fulfil the enlarged demand. To meet the growing demands, emerging innovative practices need to be introduced which can be observed as Agricultural Intelligence and can brought agriculture 4.0 revolution. Artificial Intelligence and Internet of Things like promising technologies convert traditional farming into smart agriculture by optimizing resources, reducing human labor, crop monitoring, weed handling, crop disease management, irrigation, harvesting and supply chain management. These technologies have proven for crop protection against climate changes, excess use of fertilizers, pesticides, herbicides and water for enhanced soil richness. This study presents the survey of researchers work of automation in agriculture with the support of sensors, Agricultural Robots and Drones and AI driven technologies to improve productivity. Moreover limitations, challenges and future scope of smart agriculture is also discussed in this study.
\end{abstract}

Keywords: Artificial Intelligence, Internet of Things, Agriculture, Smart Farming, Irrigation, Pesticides, Herbicides, Wireless Sensor Network

\section{Introduction}

Agriculture industry plays an essential role in World economy. Thousand years back people have started working in farm and now it has been tremendously increased and contributing a lot in global trends. Population growth, protection from environment, climate change, rich quality and quantity of food required latest tools. This has given the new dimension to researchers, engineers, scientists and business holders in the area of agriculture. In a survey, it has been mentioned that by year 2050 global population will be approximately ten billion and hence land, water and other resources may be inadequate to endure demand supply chain. Therefore, cleverer method must be identified and implemented so that farm can be extra productive. In world, Intelligence is a crucial feature which differentiate human from anything. Artificial Intelligence is an approach which can be merged into any machine or computer to make them intelligent so that they can imitate humans and accomplished task. Future of agriculture can be viewed as integrating Artificial Intelligence, Big Data and Internet of Things into traditional agriculture process (Khanna and Kaur, 2019;
Talaviya et al., 2020). Commonly used term is Smart Agriculture which is a revolution in Agriculture industry via which many local and global issues can be addressed. Use of modern technologies in Agriculture industry is to attain huge revenue by reducing the risk involved in crop failures and increasing the total harvest quality (Kim et al., 2008; Naganur et al., 2012). This drift is prospering along with increase of population, increasing food demand supply and urbanization. Bannerjee et al. (2018) proposed detailed of survey of Artificial Intelligence enabled technologies and machines because of which level of agriculture is elevated to higher level. Panpatte (2018) discussed that agricultural segment growth directly impacts the rural development and with technological support transformation can be view on world level. Jha et al. (2019) explains the role of Artificial Intelligence in various daily life applications. Automation in agriculture enhances the crop and soil monitoring, precision farming, harvesting and product commercialization. AI and IoT based smart technologies (Bashir and Sharma, 2012; Zadokar et al., 2017; Singh and Misra, 2017) with image processing have made a wonderful contribution for disease identification at initial level so enhances crop 
productivity. Agricultural Robots and Drones via computer vision are designed to perform various task like weed handling, seed sowing, disease detection and irrigation (Schor et al., 2016; Ahirwar et al., 2019). Savitha and Uma Maheswari (2018) demonstrated smart irrigation approach in agriculture field by using moisture and temperature sensors. In this study authors aim to explain the difficulties faced by farmers while doing farming via traditional approach. Use of AI and IoT has replaced traditional way of farming and serve the world to be at better place.

\section{Current and Future of Agriculture}

Agriculture is one of very significant economic sector in India because large percentage of population is dependent on agronomy. Approximately $60 \%$ of economy comes from agricultural sector but farmers face many challenges because of lack of technological awareness and implementation due to economic condition. Human labors are required at every stage which increases cost, increases time to complete task, increases probability of error and wastage which totally impact the crop quantity and quality. Figure 1 demonstrate the lifecycle of Agriculture; the function of different parts is as follows:

- Soil Preparation: Preliminary stage of farming where farmers responsibility is soil preparation for seeds sowing. The process comprises of cleaning remains and making soil uniform, adding fertilizers etc.

- Spreading Seeds: Climate condition like weather, temperature, humidity, snow fall, rain fall etc. impacts a lot at this stage. Extra precautions need to be taken for distance between two seeds and depth for implanting seed

- Addition of Fertilizers: Nutritious and healthy crop is the prime requirement which entirely depends upon the soil productiveness. Therefore, soil fertility is the key factor and farmers tend to add fertilizers as per the requirements. Fertilizers contains nutrition required for plants like potassium, nitrogen and phosphorus, which provides supplement to farming field

- Irrigation: Soil must be moist and required humidity needs to be maintained. Quality of crop depends upon the appropriate amount of watering because overwatering or under watering may damage crops and sometimes hinder crops growth also

- Weed Safety: Undesired plants near to crop or at the boundary is known as weed and hence weed protection is very much required. Weed directly impact the crop quality. When weed quantity increases, it hinders the crop so that manufacture cost increases and lastly crop quality deteriorated
- Harvesting: Process of assembling ready crops from the farm is known as harvesting. Majority of workers are required for this task. Some of the post harvesting techniques are: Categorization, packing, preservation, cleaning etc.

- Storing: This is the post harvesting job where yields are stored in secured manner i.e., food product quality is kept intact. Sometimes packing and conveyance are also required for crops

India is a land of numerous soil and varying weather condition. Agriculture is not a very promising sector for upcoming generation from carrier point of view. Major factors are unpredictable rain fall, less crop growth, ground water shortage, plant disease and commercialization of farms towards residential development. Figure 2 demonstrate the challenges faced by Farmers while doing farming in traditional means.

Agriculture sector is in-fact in necessity of technological integration which minimizes human labor at every stage to make overall process smart. Evolution of agriculture yield depends upon weather, soil attributes, humidity, environment temperature. Within past few years Machine Learning, Internet of Things, Cloud Computing, Wireless Sensor Networks have evolved a lot which contributes in monitoring and forecasting agricultural activities (Elijah et al., 2018; Liu et al., 2019). Agriculture management concept is the trend now based on recent technologies, provides decision making capability. $21^{\text {st }}$ century farmers have smartphones so they have easy access of GPS, AI and IoT enabled techniques for remote monitoring, soil scanning, disease identification and treatment, sufficient watering and harvesting.

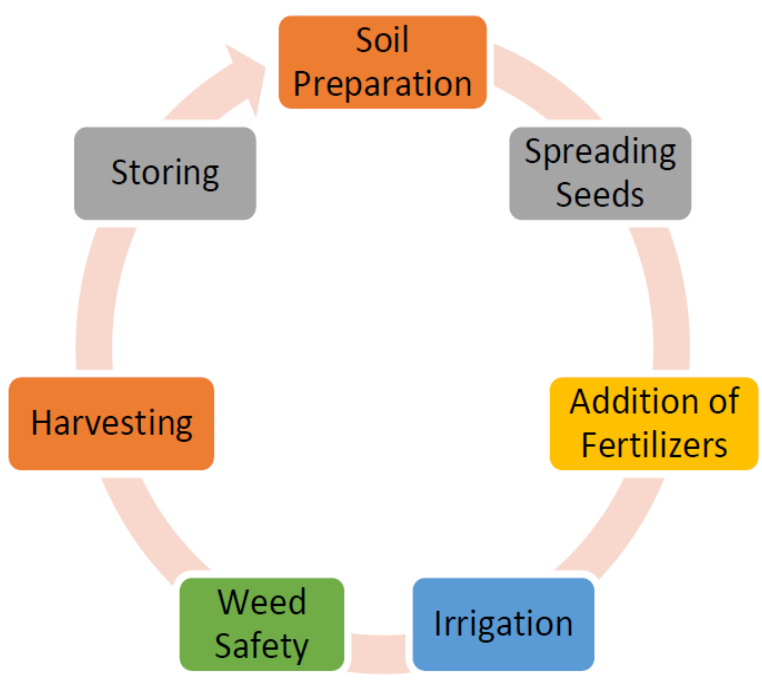

Fig. 1: Lifecycle of Agriculture 


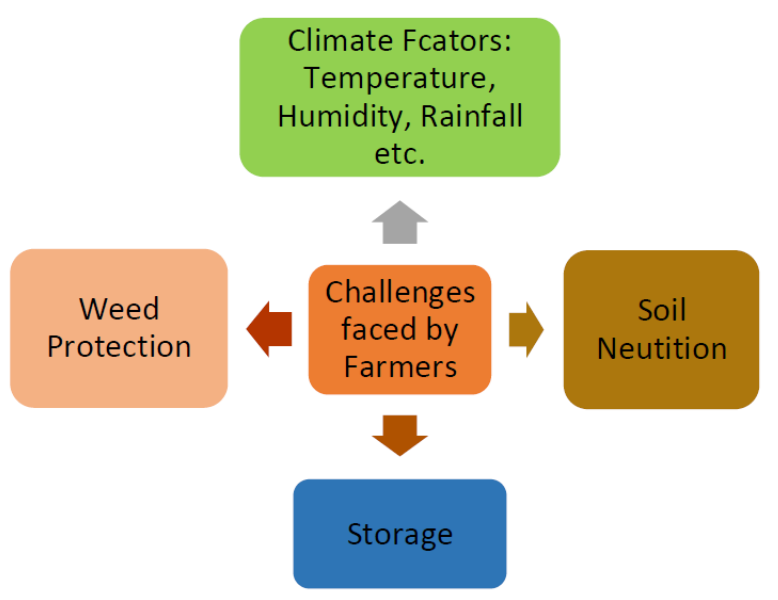

Fig. 2: Challenges faced by Farmers

\section{Power of AI and IoT on Agriculture: Smart Farming}

Smart farming can be viewed as the future of agriculture. It is a promising idea which evolves farm management using most recent technologies such as Robotics, Drones, Internet of Things (IoT), Artificial Intelligence (AI) etc. and is discussed by Seem et al. (2022). The objective of smart farming is to optimize human labor along with other required resources and to increase quality and quantity of products. Advantages of integrating modern tools, farmers can easily supervise farm situation in distant mode and take strategic decisions. Figure 3 shows the summary of recent technologies available for farmers such as placing sensors in farm, using specialized software's, connectivity, location principles. Data analytics etc.

Data is the heart of IoT, which is efficiently drawn from things and which can be transmitted over internet. To make traditional farming smart, IoT devices need to be installed on land, from where they gather and process data in repetitive approach. Therefore, farmers are enabled for quicker response, decision making for promising issues along with dynamic environment condition. IoT based Smart Farming Cycle is demonstrated in Fig. 4:

- Examination: Sensors placed in farm send observed data from soil, crop, farm animals, environment etc.

- Diagnostics: Sensors recorded data feed to the IoT platform. It is executed with predefined models and rules. Diagnostic may be in the form of some object or land identification and any deficiencies or requirements

- Decision: When problems/issues are discovered then decision about required action need to be taken. Action may be performed by user or some machine and may be location dependent also

- Action: After estimation and accomplishment of end user the complete cycle repeats
Agriculture industry is revolving around Artificial Intelligence enabled approach also to help farmers for crop quality, crop monitoring, pest control, soil monitoring, seed propagating, reducing human labor, optimize resources, harvesting, packaging, storing, a multitasking, optimum planting, nutrition management and food supply chain related things. Therefore, Artificial Intelligence and Internet of Things together can transform the conventional farming techniques into smart farming and hence Smart Agriculture can be viewed. Figure 5 shows the classification of AI and IoT based applications for Smart Agriculture.

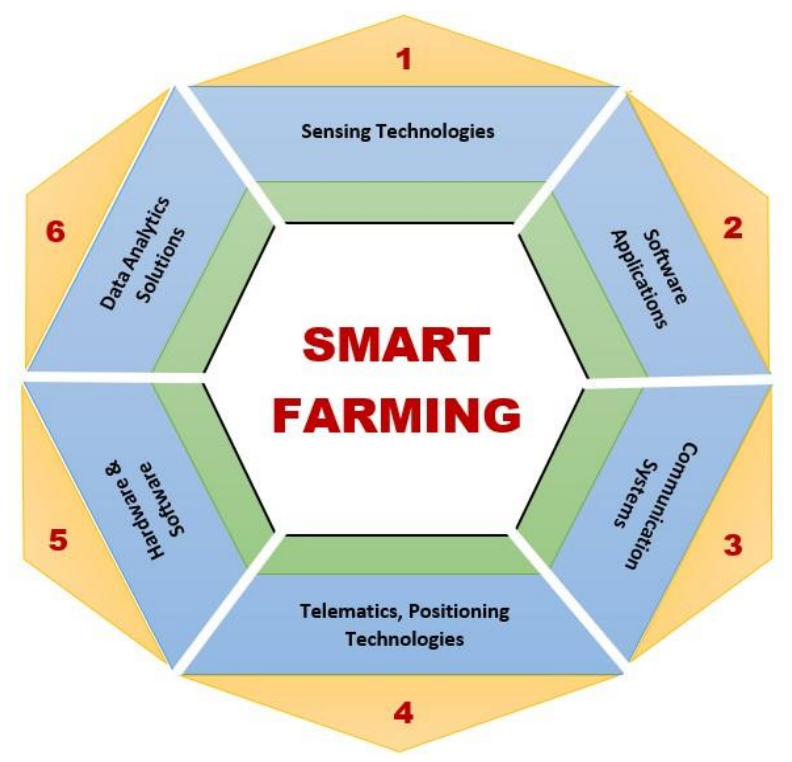

Fig. 3: Summary of recent technologies in agriculture

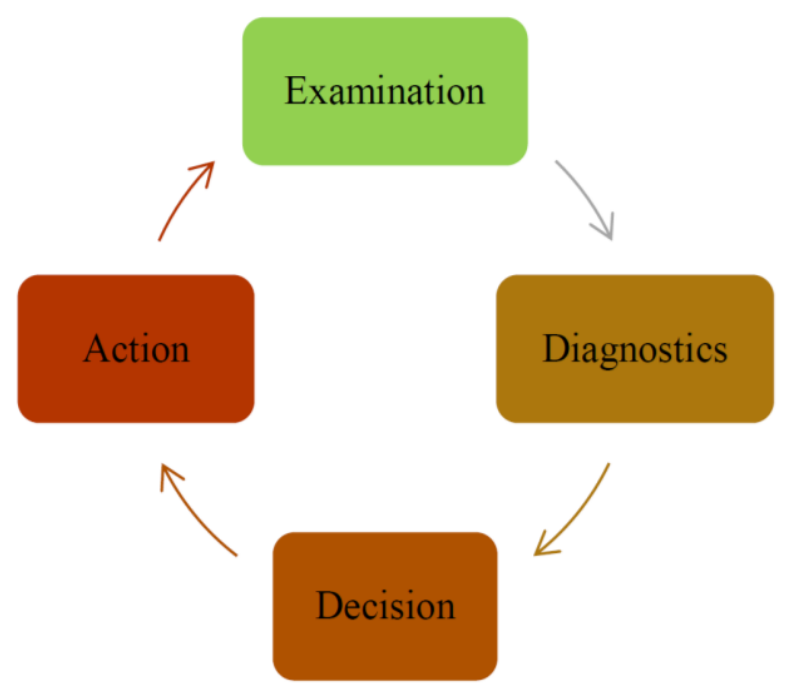

Fig. 4: IoT based smart farming cycle 


\section{AI ans IoT Applications for Smart Agriculture}

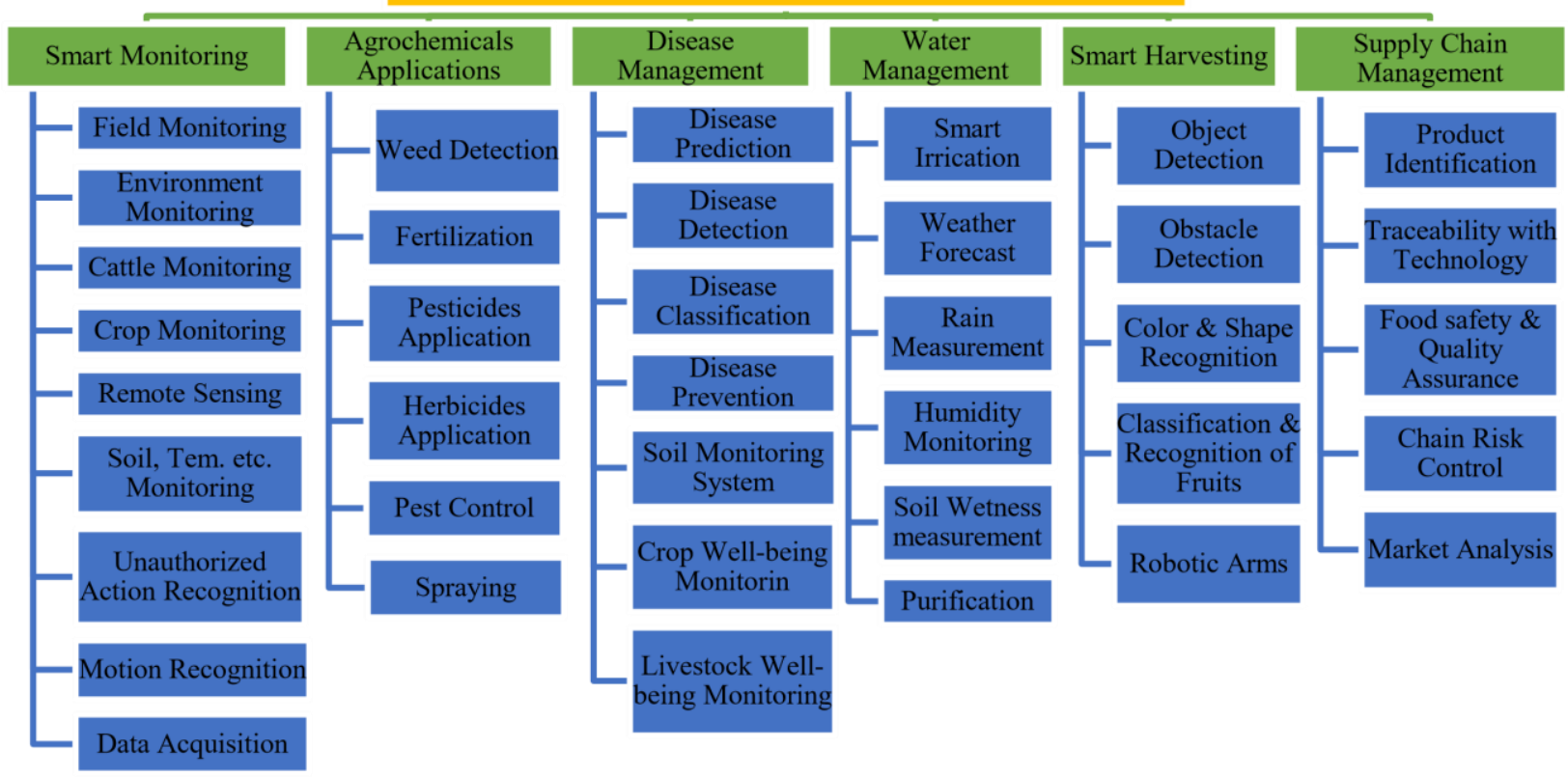

Fig. 5: Classification of AI and IoT technologies for smart agriculture

\section{A. Smart Monitoring}

Artificial enabled IoT based smart systems contribute to preserve perfect conditions so that quality food products can be grown. In previous years, agriculture industries have been developed a lot in terms of monitoring.

\section{Field Monitoring}

To monitor farm field, variety of sensors are placed which keep sending acquired data to central process which uses some software's to analyze it. Alternatively Unmanned Aerial Vehicles (UAV) are now very popular in agriculture, is known as Agriculture Drones. They contribute very effectively is smart agriculture as capable to collect data from farm for monitoring and analysis. Sometimes advanced features are integrated in drones and they can accomplish various tasks earlier performed by human labor like seed sowing, removing weed, crop planting, spraying, pest control, harvesting, packaging etc. Gondchawar and Kawitkar (2016) demonstrated GPS controlled Robot used for distant monitoring and field data control. Realized a real time smart decision system prototype for digital farming. Depending upon the nature of data available, irrigation procedures, farm factors and weather circumstances, system automatically acquires conclusion rubrics (Cambra Baseca et al., 2019). Ahmed et al. (2018) demonstrated precision architecture and smart farming for rural areas with an objective to cover prolonged range using Internet of Things.

\section{Environment Monitoring}

Technology plays a critical role to understand and predict environment, Internet of Things is one of them. Environment monitoring is related to techniques offered to sense the environment with the help of sensors and getting real time statistics about soil, weather, air and water. Data send by sensors are analyzed for the further farmer actions like changes in seed sowing plan, modification in harvesting, variation in irrigation schedule for crop quality improvement. Lai et al. (2019) demonstrated Kalman Filter (KL) algorithm for refining precise prediction and monitoring of air quality using IoT technology. Accuracy of $27 \%$ has been reflected in results and errors are declined by $68 \%$ with IoT application. Harun at al. (2019) discussed how Brassica Chinensis is progressing in precise atmosphere when light parameters are varied. The relationship among atmosphere, light and plant geomorphology over IoT technology has been deliberated by authors. Lazarescu has demonstrated low cost WSN platform rich for extended term environment monitoring. This design is suitable for IoT applications and have features like readily deployable, elongated life, reduced cost, less maintenance, reduced error, uninterrupted facility with superior quality of service (Lazarescu, 2013).

\section{Cattle Monitoring}

Agriculture sensors IoT based can be included and attached with the farm animals so that their well-being and act can be recorded. Livestock monitoring and following supports to acquire information about cattle health, 
location etc. These sensors even recognize and inform farmers about which cattle is sick or injured so that same can be detached from a group to avoid any further spread of infection. Large farm owners can use Drones for tracking the cattle and it reduces and sometimes eliminated the human labor involvement.

\section{Crop Monitoring}

Crop monitoring is related to the recognition and nursing the crop wellbeing, which can be undertaken by using AI enabled algorithms and IoT sensors or RFID chips. Important parameters monitored by sensors positioned in farm are: Soil characteristics, humidity, disease detection, animal disturbance, pest detection etc. Triantafyllou et al. (2019) demonstrated an application for saffron agriculture monitoring in Greece. Component organization for smart agricultural monitoring system using Internet of Things in support with energy saving protocols. Morais et al. (2019) demonstrated the data procurement procedures defined as my Sense environment. It is a four-level high-tech structure consist of sensor nodes, links, cloud facilities and provision for software applications of users. To improve the implementation of crop monitoring, technologies are integrated to achieve low cost, speedily deployable, highly accurate along with optimized resources.

\section{Remote Sensing}

It is used to procure information on the basis of electromagnetic radiation interaction. Instead of absorbed or emitted radiation, it considers the reflected radiation (Mulla, 2013). Furukawa et al. (2020) demonstrated that Unmanned Aerial Vehicles (UAV) are used for corn crop monitoring. Corn height estimation is carried out using 3D Photogrammetry technology. In the field of smart agriculture, remote sensing has found numerous application:

- Crop production

- Crop damage

- Crop progress

- Crop identification

- Cultivation

- Stress detection

- Prediction of expected crop

- Pests' identification

- Disease infestation

- Soil moisture assessment

- Irrigation monitoring

- Irrigation supervision

- $\quad$ Soil mapping

- Soil management

- Crop nutrition shortage recognition

- $\quad$ Flood mapping and monitoring

- Weather data acquisition
- Precision farming

- Climate change monitoring

- Crop quality analysis

- Land mapping

- Humidity estimation

\section{Soil, Temperature etc. Monitoring}

To grow crop in quality and quantity, every farmer must be aware about the suitable soil and surrounding temperature requirements. Soil may face numerous threats often such as corrosion, contamination, acidification, compaction, damage in organic material, biodiversity degradation etc. sometimes Soil characteristics like $\mathrm{pH}$ value, moisture, nutrition value may vary with time so IoT sensors and AI algorithms can identify/record changes and send data to farmers. Accordingly, farmers can take decision to prevent crop from threats, environment temperature variations and for use of nourishments as per the nature of crop. Hirsch et al. (2019) demonstrated a suitable IoT environment for monitoring temperature and soil humidity in farm as well as at home. Influence of environment on growth of plant has also deliberated in low power and upgradable architecture based on IoT.

\section{Unauthorized Action Recognition}

Illegal movements of humans and wild animals must be restricted in farm to protect crop. It is always very expensive to monitor large farm field via human labors, probability of error also increases here. With technological developments in Artificial Intelligence, Internet of Things etc., various security systems, alarms have been developed and effectively deployed in fields. Several methods are there to avoid intruder detection. One is to place camera in field and when it detects any kind of motion or malicious activity, necessary action will be taken. Muminov et al. (2019) presented a computer-generated fencing application in farm to monitor and restrict goats' movement. Intelligent GPS collars are used and approximately $20 \%$ of goats have probability of getting electrical stimulus and it is only when goat is in threatening zone. Electrical stimulus is applied to goat depending upon the posture if they are neither stopped or returning in warning zone. Potamitis et al. (2019) demonstrated sensor based automatic device for trees surveillance on large farm land. It uses an accelerometer for insect investigations and this device continuously transmits short vibrations from inner portion of tree to server located at remote location. Author also presented the use of same device at global scale for other situation applications like prohibited tree cutting, restricted tree movement recognition, detection of wood pests in trees etc.

\section{Motion Recognition}

Artificial Intelligence enabled approaches are very powerful in motion detection. Passive Infrared sensors 
located in fields detect movements in supervised areas. Researchers have presented and applied various techniques and tools. Liu et al. (2019) established and demonstrated modern system based on Internet of Things for agricultural land monitoring. Developed system is intelligent, low cast, durable, scalable, capability of motion detection and gather data as well as control equipment in distant mode.

\section{Data Acquisition}

Multimedia data capturing is essential to process and extract beneficial data from images, videos etc. and Artificial Intelligence supports to make overall process smarter. Physical environment of real time agricultural land can be simulated in adaptive scenario to extract image attributes required for particular applications. Kurihara et al. (2020) demonstrated the practical features of hyper spectral imaging system involving Unmanned Aerial Vehicles (UAV). This high-tech system is suitable for precision agriculture and managing forest using image processing.

\section{B. Agrochemicals Applications}

Researchers have listed about the yearly agricultural loss of approximately 20 to $40 \%$ of total production therefore some fertilizers or pesticides are required. Agrochemicals are the variety of chemicals used for agriculture, it may be manures, chemical fertilizers, insecticides, weed killers etc. Sometimes the mixture of two or more materials are used to improve crop quality, controlling pest in farms, prevent disease and preserve the food for longer time duration. Perfect quantity of pesticides needs to be added else overuse may damage crop or harm the atmosphere and human wellbeing. AI algorithms and IoT sensors can sense soil attributes and help farmers to take necessary actions for minimizing waste and improving crop quality.

\section{Weed Detection}

Generally, weed is any unwanted plant grown in farm and farmers had to fight with it, weed impacts a lot on crop growth. Weed elimination is the major mission because it hinders various human actions. Integration of Artificial Intelligence, Image Processing and Internet of Things have developed promising means for precise real time weed recognition in farm ground. Lottes et al. (2018) explains the weed recognition and classification for accurate farming. Image sequences segmentation is carried out by fully convolution networks in terms of pixels, soil parameters, crop attributes and weed nature. Potena et al. (2016) designed and demonstrated real time precise weed classifier which supports fast and exact crop development. It is accomplished by summarized training set with high accuracy where camera is located on agricultural robot.

\section{Fertilization}

To grow the harvest and increase crops productivity, farmers used to add organic materials in land is known as Fertilizers. Basically, three plant nutrition's exist in fertilizers: Nitrogen, Phosphorous and Potassium. Some other varieties of fertilizers are sometimes used by farmers are Calcium, Sulphur, Magnesium, Macronutrient type, inhibitors etc. Technology plays an important role to add on nutrients time to time or by recycling nutrients. Lavanya et al. (2020) demonstrated AI and IoT based intelligent system where sensors sense the data corresponding to the Nitrogen, Phosphorous and Potassium levels in soil. Sensors anticipate the colorimetric process by LDR and LED. Fuzzy rule-based system designed by researcher, analyses the information and instruct farmer to take necessary action.

\section{Pesticides Application}

Chemical materials which are used to kill insects are known as Pesticides, which is used by all farmers. Use of pesticides in agriculture may also damage the crop quality and quantity. AI and IoT based system facilitate the farmers to unnecessary use of insecticides. Lee et al. (2017) describes an IoT based smart system which minimizes the pesticides usage in fruit trees. This system is also capable to predict the presence of pests in varying temperature and humidity environments.

\section{Herbicides Applications}

In agricultural field, Herbicides are used to control weeds density and endorse crop health. Mostly herbicides remain lively in atmosphere for longer duration and may cause water and soil contamination. Sometimes the herbicide degradation residue may contribute toxic in atmosphere. Arakeri et al. (2017) demonstrated an intelligent system comprises of Machine Learning, Image Processing and Internet of Things. This robotic system is capable to categorize weed from crop using computer vision and apply appropriate quantity of herbicides.

\section{Pest Control}

One hazardous enemy of farmers is Pests, which may damage the crop quality if not treated on time. Artificial Intelligence has given a very effective approach to handle it. Acquired images are compared with reference image by AI algorithms. Sensors gathers data automatically which identifies the presence of pests, impact of insect if any and even the kind of insect. Farmers can receive alerts, reports and monitor their farm from smartphones and hence farmers can get support to fight against pests. Yue et al. (2018) anticipated and explains automated high-tech prototype for pest observation and detection using Laplacian pyramid technique. Results have shown the evidence of developed system performance. 


\section{Spraying}

Crop spraying is also recognized as crop dusting. In spraying process, the chemicals are diluted in water and then crop is covered with it so that pests must be killed. With the advent of technology, Aircrafts, Unmanned Aerial Vehicles are used for spraying purpose which reduces time and cost involved in spay. Faiçal et al. (2014) describes UAV based model used for spraying in farm. Adaptive algorithm is used to compute UAV path in real time environment with dynamic wind strength and direction where wastage is also reduced.

\section{Disease Management}

In Agricultural farm crop quality and productivity increases if plant disease is controlled. Emerging technologies like AI, ML, IoT are effectively preferred for disease management to minimize losses and increase harvest. Now a days many algorithms, applications, apps have been developed through which farmers can monitor their land and get notification on their smart phones.

\section{Disease Prediction}

Crop diseases may be in the form of bacteria, virus, pest, fungi, micro-organism etc., which may have harmful impact on animals or plants. Therefore, overall impact is on market scenario and production of agriculture products. Khattab et al. (2019) demonstrated an intelligent IoT based monitoring structure for several plant disease at initial level. Monitoring system provides the information about favorable environment to grow crop optimum and forecast rate of disease spreading quickly.

\section{Disease Detection}

Precise and quick plant disease diagnosis plays very important role in agricultural products production and in minimizing crop quality loss. Traditional way of disease diagnosis is via visualization by human eye, through microscope, microbiological etc. AI and IoT makes the process smarter, sensors help for automatic disease recognition in remote. Zhao et al. (2020) demonstrated such model with deep learning approach for visual features by taking thousands of samples. With such type of system crop disease identification accuracy is achieved up to $97.5 . \%$.

\section{Disease Classification}

Basically, plant illness is classified into two categories: Infectious and noninfectious. Infectious diseases are triggered by virus, protozoans, eukaryotes etc. while noninfectious disease is because of external atmospheric conditions. Researchers have proposed many models based on deep learning algorithms for plant, leaf, animals' disease identification. Kale and Sonavane (2019) explains intelligent decision support system for agriculture using sensors. This model is applied to a large data base of plant disease as well as in real time scenario and it proves that classification efficiency is increased.

\section{Disease Prevention}

AI enabled and IoT based newly developed models can prevent disease so that it would not affect the agricultural production. Park and Park (2011) implemented greenhouse environment monitoring using wireless sensor networks. This model is also capable to avoid dew condensation on crop leaf so that crop production increases.

\section{Soil Monitoring System}

Quality of crop and its development entirely depends upon the kind of soil and its nourishment. Now a days soil quality is degrading as disforestation is growing. Plantix is an AI enabled application app developed by German which is based on image recognition. It is capable to recognize the nutrition insufficiencies in soil. Therefore, farmers will get to know about use of fertilizers to recover crop quality and hence productivity increases. One more ML based company Trace Genomics is working in same domain and support farmers to do soil analysis.

\section{Crop Well-Being Monitoring}

Farmers have a responsibility to regularly monitor crop health to increase production. To perform this task manually, tremendous efforts need to be done. Technological inclusions made the system smarter. SkySqurrel Technologies is a company which works on drone-based approach for crop health monitoring. Drone capture the images from farm and AI based algorithms analyzed these images and provides comprehensive report to farmers. On the basis of report farmers can take preventive measures in terms of pests, fertilizers or any other essential action. Kim et al. (2018) demonstrated IoT based system for predicting disease in strawberry. This system collects the data from sensors, process it to the clous, analyze and forecast the details or precautionary measures. Pantazi et al. (2019) described an algorithm for feature analysis in image to recognize crop disease multiple crop classes. Multiple tests were conducted on plants where $95 \%$ of victory rate was achieved.

\section{Livestock Well-Being Monitoring}

Diseases of livestock can be recognized if regularly monitored, even their behaviors, feeding and actions can tell us about the problem they are suffering. Kumar and Hancke (2014) developed a Zigbee based prototype for cattle health monitoring. It is a low power, low cost, sensor based, small size, easily manageable, superior quality with great accuracy model.

\section{Water Management}

Water resource management in agriculture is essential for farmers in terms of crop growth, maintaining soil and 
particularly for sustainability. IoT technology makes it smarter and sometimes known as smart irrigation system or smart water management. Sensors are used in farm, which senses and send required real time data through ICT and wise decision can be taken. This makes the overall system smart and efficient and hence cost involved is reduced, manual labor is not required, no monitoring is required, time involved is reduced while harvest quality is enhanced.

\section{Smart Irrigation}

Automation in irrigation or smart irrigation system is proficient in identifying the water requirement of each plant in farm. Traditional irrigation practice needs human intervention while smart irrigation is automatic and reduces human labor. Smart irrigation system reduces time, water, farmer efforts because various sensors placed in farm senses parameters like soil moisture, humidity, temperature etc. On the basis of data received from sensors, decision about irrigation is to be taken whether to irrigate or not. Kamienski et al. (2019; Nawandar and Satpute, 2019) demonstrated IoT based model for smart irrigation with high precision. Overall process of water management is categorized into three parts: Water supply, water distribution and water consumption. Real time data acquisition, analysis about various trees or plants, soil attributes and environment conditions can be personalized by the users.

\section{Weather Forecast}

Propagating seed at precise time is a key factor for crop health. During the varying climatical circumstances, farmers need to find out the appropriate time for seed sowing during increased pollution environment. Along with it, schedule irrigation in agriculture farm is also very much required. Artificial Intelligence based algorithms can investigate whether circumstances by using weather forecasting and water requirement in farm. It helps farmers to plan which crop is to grow and what is the appropriate time for seed propagating and watering. Goap et al. (2018) projected an intelligent automated prototype which uses sensors. It is efficient to predict soil humidity in forthcoming days depending upon weather forecast.

\section{Rain Measurement}

Farmers are totally dependent on rain for crop irrigation and rain gauge is a equipment used to measure rain rate. In the technological era, rain sensors are proficient to predict rainfall. Severino et al. (2018) proposed intelligent system consisting of sensor network. This network capture soil humidity and dissolved pollutants concentration and proposed model predict the agricultural dynamics. Therefore, water irrigation can be optimized and even optimization can be applied different sectors of the same farm.

\section{Humidity Monitoring}

Humidity sensors can be used to quantity the humidity content in an air. Keswani et al. (2019) developed an IoT based wireless sensor network system with many sensors like: Humidity, light intensity, carbon di oxide, environment temperature and soil temperature to estimate amount of water needed for irrigation. The proposed system is adaptive and successfully predict values even in unfavorable weather conditions.

\section{Soil Wetness Measurement}

Estimation of soil wetness depends upon dryness level and extent of water extracted. Indirect methods are effectively used for such type of task. Angelopoulos et al. (2020) proposed an intelligent system for strawberry greenhouse irrigation. Soil moisture sensors are placed in every container along with motor-controlled valve to avoid wastage of water. This type of model is efficient to eliminate old styled approaches of watering and water consumption.

\section{Purification}

Purification process is also known as desalination, which is advantageous for agriculture. This process segregates undesired salts from sea or salty water and eliminates ions, both are important for crop growth as fresh water is the boon of agriculture. Two methods of purifications are there: Seawater Reverse Osmosis and Brackish Water Reverse Osmosis. Yaqub et al. (2019) demonstrated a hybrid purification plant which uses solar and wind energy. This type of system is extremely efficient even for industrial context which reduces operational cost and probability of error.

\section{E. Smart Harvesting}

Manufactures have developed various automated harvesting system for smart agriculture commercial purpose. Researchers have computed that automation in agriculture has reduced the harvesting cost approximately $40-45 \%$, simultaneously large revenue is recovered from agroindustry.

\section{Object Detection}

Object detection is a kind of computer vision technique, this process depends on image processing. The objective of object detection in agriculture is to recognize and detect required objects in any image or video. It can be used to identify distinct objects, counting objects, separating some specific class of objects etc. Lin et al. (2020a) developed a technique for detecting types of fruits using Hough transform and shape matching. Results were observed on 450 natural atmosphere images and show that algorithm is efficient with fast convergence. 


\section{Obstacle Detection}

Now a days many processes of agriculture are automated, no manual labor is involved there but sometimes obstacle may hinder the process. Therefore, obstacle detection is required and especially during the movements of autonomous vehicles in agricultural field. Still a lot of research is need to be done for this, though path optimization, navigation, crop monitoring, irrigation, harvesting etc. have been explored a lot. Sometimes the outer agricultural environment is heterogeneous so deploying a security system is not feasible for autonomous vehicles. Bac et al. (2013) proposed an obstacle plotting system for sweet-peeper for smooth movement of harvesting robot. In this approach soft and hard obstacles have been separated initially in dense environment and to robot manipulators are used to sweep obstacles sidelong.

\section{Color and Shape Recognition}

In case of vegetables or fruits, color and shape the possible the attractive attributes upon which agriculture depends. Product appearance is upon which product acceptability depends, acception or rejection and hence color appearances are crucial. To perform such task in agriculture, artificial vision system of image processing is used, where some algorithms are applied for shape and color identification. Lin et al. (2020b) developed an algorithm for harvesting robot, which is capable to pick the fruits on the basis of three parameters: Color, depth and shape.

\section{Classification and Recognition of Fruits}

Efficient detection and precise recognition of fruits is a significant requirement in fruit harvesting system. Amalgamation of Artificial intelligence and image processing made the fruits segregation process automated in real time adaptive environment. Wan and Goudos (2020) demonstrated smart real time robotic vision model for multiple class fruit detection, which uses region-based convolution neural network. Three types of fruits i.e. mango, apple and orange; have been recognized with an accuracy of more than $90 \%$.

\section{Robotics Arms}

Harvesting is one promising field in agriculture where robots can make the process smarter with reduced cost, time, error. Barnett et al. (2020) examined the harvesting task partitioning by using multiple robot arms for kiwi fruit in shortest time interval. One more researcher applied and demonstrate robotic arm for tea leaf pulling. Action is taken on the basis of quantity required, sample image, visual movement etc.

\section{F. Supply Chain Management}

In the field of agriculture, Supply Chain Management (SCM) indicates handling association between production responsible for well-organized production and product supply from farm to consumers to meet their requirements with respect to availability, quality, quantity and cost. SCM is a five-pointer system: Plan, source, make, transport and return. AI and IoT technologies have made the promising changes is supplying healthy food in structured manner.

\section{Product Identification}

Any agriculture yield may fall into one of the four categories: Fuel, food, raw material, fiber. In an industrial automation, RFID tags can be widely used to recognize, classify and managing product flow. Leng et al. (2019) explained IoT based agricultural product identification technique. RFID is used for supply chain scrutiny and this system shows efficient approach.

\section{Traceability with Some Technology}

Food safety is the major concern among all of us therefore traceability is the need which demand some recent technology also. Traceability is a type of risk managing tool which must have the capability to recognize food origin, food ingredients and sources. It is very much required especially when food product is found faulty. In traceability scheme, any organization must keep record of every stage of food processing till distribution. Block chain technology can be effectively used in traceability, it is a distributed data structure which can be shared among all network members. Artificial intelligence approach can be united with block chain and internet of things to attain safe smart agriculture. Caro et al. (2018) proposed a block chain based decentralized solution for traceability, applied for supply chain management. This system is transparent, unchallengeable and can also solve real time problems

\section{Food Safety and Quality Assurance}

Food safety of agricultural products is the prime responsibility as it directly impacts the health of individuals. Sahni et al. (2021) and discussed about food safety is a large domain which includes variety of processes, production in farm, food processing, food distribution, food storage, assortment and consumption. Food industries maintain quality assurance, which is a set of actions to guarantee that developed food products meets defined conditions and standards. Internet of things technology contribute a lot in the food environment monitoring and surveillance of crop. It continuously shares the real time data among consumers and administrators. Rajakumar et al. (2018) proposed an IoT based smart system to check contamination in milk. Different types of sensors like gas, temperature, humidity etc. are used in system to monitor and control food quality.

\section{Chain Risk Control}

It is the capability to recognize hazards instantly in food supply chain to guarantee advanced level of security 
for customers and manufacturers both. Wang and Yue (2017) demonstrated food protection system which tracks all required data during the entire supply chain. This system alerts food manufacturers in case any hazard in food is being identified. This type of model can efficiently recognize safety dangers and precisely determine and raise the alert to expert.

\section{Market Analysis}

Agriculture market analysis is a large-scale approach which helps to create opportunities for farmers, manufacturers and business owners. From simple farmer to large super market, agriculture impacts the price, value, volume etc. The objective is to deliver judicious and impartial market perception which help farmers to understand market trends, marketing strategy, product sale and product delivery. Sun et al. (2019) proposed mobile crows sensing approach to improve existing agricultural data gathering arrangement. Farmers having smart phones will be able to receive immediately agricultural information from farm.

\section{Agricultural Robots and Drones}

Agriculture seems to be high-tech industry now because of the inclusion of innovative experts, firms and many more stakeholders. Technological development is quick and attractive to meet the food demands with automation and robotics. Agricultural Robots are dedicated to assist farmers in multiple tasks. Robots can be programmed to examine, automate, repetitive and intensive kinds of tasks and hence the burden on farmers can be reduced (Schor et al., 2016; Arakeri et al., 2017). This increases overall production efficiency. Companies working in AI domain are developing Robots which are capable to accomplish multiple tasks in farms (Bac et al., 2013; Barnett et al., 2020). Few important tasks performed by Robots in agriculture are shown in Fig. 6 . These tasks are very much difficult to automate but Robot can perform these very effectively even in the presence of multiple obstacles.

Using Drones also in Agriculture sector is progressive and proven very effective supportable agricultural management. Agriculture Drone is an Unmanned Aerial Vehicle (UAV) which helps in optimizing human labor, agriculture operations, crop monitoring, increasing crop quality and quantity (Faiçal et al., 2014). Product readiness process becomes very efficient with use of GPS, every step can be monitored which enhances efficiency and profit increases. Computer vision technology helps high resolution drones to get accurate information, crop fertility, disease identification and wastage reduction. Figure 7 represents some important tasks performed by Drones in agriculture are shown in. Technology can be further enhanced to protect farmers from natural disaster.

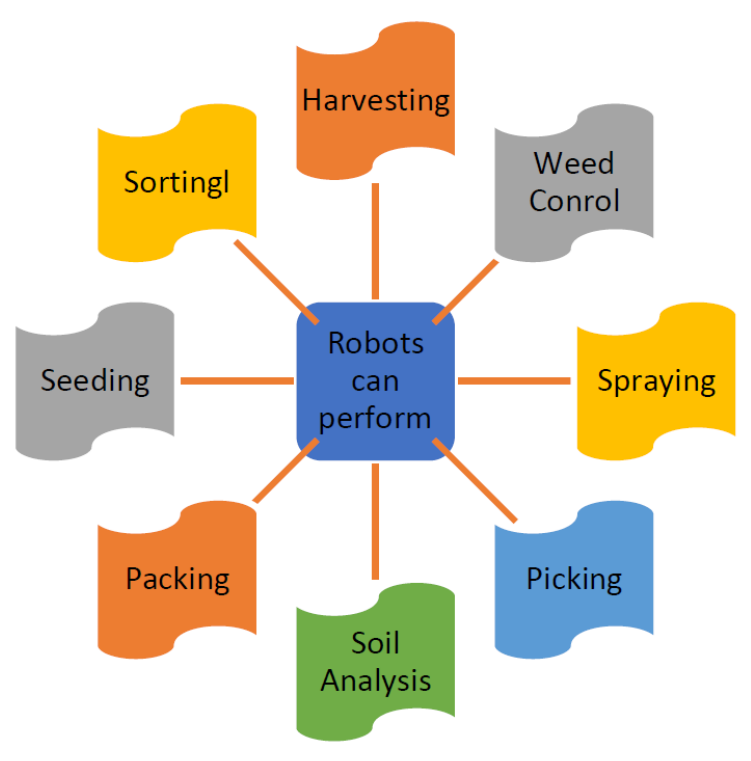

Fig. 6: Tasks performed by agriculture robots

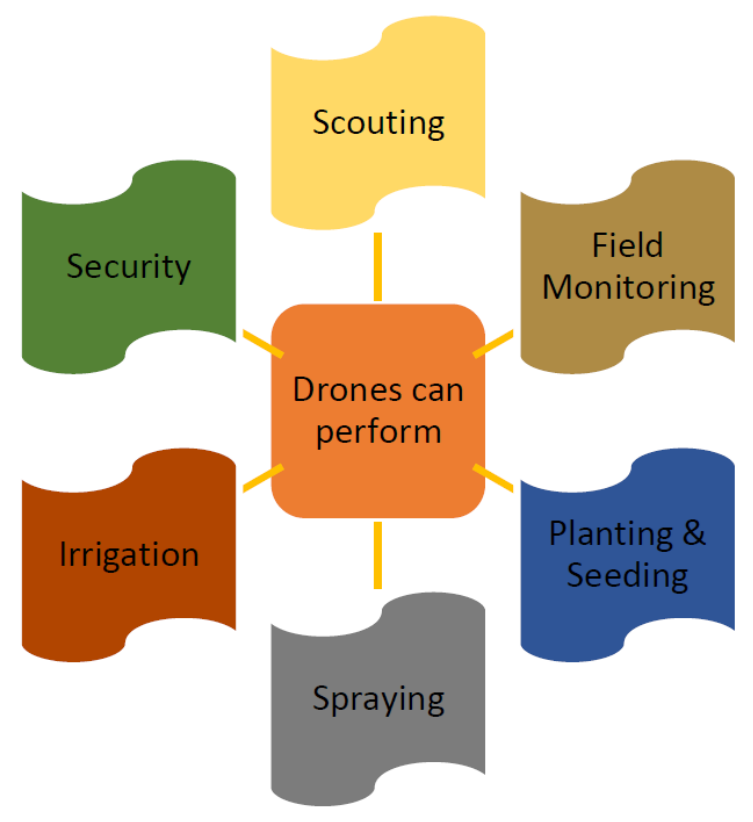

Fig. 7: Tasks performed by agriculture drones

\section{Discussion and Future Scope}

Agriculture domains encounters with many challenges starting from soil parameters, seed sowing, crop growth and its quality, weed handling, disease management till harvesting and storing crop. Artificial intelligence driven techniques along with other available tools and automation can address these challenges and proven the revolution in agriculture. Most popular AI application in agriculture is use of Robot and Drones, they perform 
almost all task like humans even at a faster rate with accuracy. From literature review it is clear that precision farming is probable by integrating sensors, cameras, data analytics, GPS and remote sensing. Image recognitions software's, IoT sensors can be used for disease recognition at primary stages and hence crop health can be supervised which increases superior quality production with minimum loss. Table 1 demonstrate the various applications in view of Smart Agriculture for improved evolution as well as superiority. Still there are several challenges associated with AI and IoT application in smart agriculture which is the promising future to be explored area for researchers. Some of major challenges are:

- Awareness issues

- Hardware implementation challenges

- Cost of software and hardware
- Network management

- Energy management

- Privacy issues

- Security challenges

- Interoperability of systems

With the induction of Computer vision, Deep learning, Big data also agriculture sector has influenced a lot. Researchers can integrate IoT sensors along with smart systems and computational optimization algorithms to overcome the limitations/shortcomings. Smart Agriculture has a budding potential towards productivity, precision, optimization, adaptive resource management and intelligent food traceability. It will contribute to environment also in terms of efficient use of water, prevent disease contamination and precise use of pesticides.

Table 1: Various applications of smart agriculture

\begin{tabular}{|c|c|c|c|c|c|}
\hline S. No & Reference & Applications & Technology/Algorithm & Results/Description & Limitations/Future scope \\
\hline 1 & $\begin{array}{l}\text { Khanna and } \\
\text { Kaur (2019) }\end{array}$ & Precision Agriculture & $\begin{array}{l}\text { Sensors for data collection, } \\
\text { Wireless Communication } \\
\text { Protocol, Internet of Things }\end{array}$ & $\begin{array}{l}\text { Discussion about the most prominent applications } \\
\text { in the field of IoT have been highlighted and a } \\
\text { comprehensive review in the field of Precision } \\
\text { Agriculture has been done. }\end{array}$ & $\begin{array}{l}\text { Existing challenges can be further } \\
\text { improved upon with more inspiring } \\
\text { and innovative ideas. }\end{array}$ \\
\hline 2 & Liu et al. (2019) & $\begin{array}{l}\text { Modern Eco- } \\
\text { Agriculture }\end{array}$ & $\begin{array}{l}\text { Internet of Things, Cloud } \\
\text { Computing, Bigdata }\end{array}$ & $\begin{array}{l}\text { Development and construction of modern agricultural } \\
\text { IoT monitoring system, intelligent gateway of the } \\
\text { IoT, MQTT message service, cloud-based } \\
\text { big data analysis works effectively. }\end{array}$ & $\begin{array}{l}\text { Integration of different technologies } \\
\text { may help in reducing the cost of } \\
\text { system development and ensuring } \\
\text { its reliability as well as security. }\end{array}$ \\
\hline 3 & Lazarescu (2013) & $\begin{array}{l}\text { Long-term } \\
\text { Environmental } \\
\text { Monitoring }\end{array}$ & $\begin{array}{l}\text { WSN Technology, } \\
\text { Internet of Things }\end{array}$ & $\begin{array}{l}\text { Need to design wireless sensors and their application } \\
\text { using WSN technology for environment } \\
\text { monitoring by using sensors. }\end{array}$ & $\begin{array}{l}\text { Sensor nodes are prone to damage in } \\
\text { unfavorable environment conditions. } \\
\text { Failure node may affect overall } \\
\text { network task to maintain system } \\
\text { reliability. }\end{array}$ \\
\hline 4 & $\begin{array}{l}\text { Triantafyllou et al. } \\
\text { (2019) }\end{array}$ & $\begin{array}{l}\text { Precision Agriculture } \\
\text { Monitoring }\end{array}$ & $\begin{array}{l}\text { Machine Learning, } \\
\text { Artificial Intelligence, } \\
\text { Internet of Things }\end{array}$ & $\begin{array}{l}\text { Overview of approaches for the segregation of sparse } \\
\text { and dense areas within a sugarcane field. }\end{array}$ & $\begin{array}{l}\text { Some innovative approaches for } \\
\text { segregation must be incorporated } \\
\text { to achieve better result. }\end{array}$ \\
\hline 5 & Talaviya et al. (2020) & $\begin{array}{l}\text { Irrigation and } \\
\text { application of } \\
\text { pesticides and } \\
\text { herbicides }\end{array}$ & $\begin{array}{l}\text { Artificial Intelligence, } \\
\text { Automation }\end{array}$ & $\begin{array}{l}\text { The various applications of } \mathrm{AI} \text { in agriculture like } \\
\text { irrigation, weeding, spraying with the help } \\
\text { of sensors and other means embedded in robots and } \\
\text { drones have been discussed. These } \\
\text { technologies save the excess use of } \\
\text { water, pesticides, herbicides. }\end{array}$ & $\begin{array}{l}\text { AI-enabled image } \\
\text { recognition will be useful. } \\
\text { Autonomous robots can } \\
\text { improve efficiency and they } \\
\text { can also reduce the need for } \\
\text { unnecessary pesticides and herbicides. }\end{array}$ \\
\hline 6 & Kim et al. (2008) & Irrigation system & $\begin{array}{l}\text { Automation, Wireless } \\
\text { Sensor Networks, } \\
\text { Smart Systems }\end{array}$ & $\begin{array}{l}\text { Communication signals from the } \\
\text { sensor network and irrigation controller } \\
\text { to the base station were successfully } \\
\text { interfaced using low-cost Bluetooth } \\
\text { wireless radio communication. }\end{array}$ & $\begin{array}{l}\text { GUI offers stable remote } \\
\text { access to field conditions } \\
\text { and real time control, which } \\
\text { can be improved for } \\
\text { monitoring of the variable- } \\
\text { rate irrigation controller. }\end{array}$ \\
\hline 7 & Keswani et al. (2019) & Smart Irrigation & $\begin{array}{l}\text { Wireless Sensor } \\
\text { Networks, Internet } \\
\text { of Things, } \\
\text { Fuzzy Logic }\end{array}$ & $\begin{array}{l}\text { The irrigation valve control mechanism } \\
\text { with fuzzy logic is applied to fulfil } \\
\text { uniform farm irrigation requirement } \\
\text { almost all the weather conditions. }\end{array}$ & $\begin{array}{l}\text { Specific crop irrigation } \\
\text { control mechanism can be } \\
\text { added for efficient irrigation } \\
\text { over a large farming area } \\
\text { With optimization } \\
\text { algorithms. }\end{array}$ \\
\hline 8 & $\begin{array}{l}\text { Angelopoulos et al. } \\
\text { (2020) }\end{array}$ & $\begin{array}{l}\text { Smart Irrigation } \\
\text { Networks for } \\
\text { Strawberry } \\
\text { greenhouses }\end{array}$ & $\begin{array}{l}\text { Smart Systems, } \\
\text { Edge Computing }\end{array}$ & $\begin{array}{l}\text { Proposed work outperforms both in terms } \\
\text { of soil moisture variation and in terms of } \\
\text { water consumption. Costs and benefits of } \\
\text { adopted approach in the agricultural proves it. }\end{array}$ & $\begin{array}{l}\text { Still there is a scope in } \\
\text { reduction of cost so } \\
\text { objective function must be } \\
\text { modified to get more } \\
\text { optimized result. }\end{array}$ \\
\hline 9 & $\begin{array}{l}\text { Savitha and } \\
\text { UmaMaheswari } \\
(2018)\end{array}$ & $\begin{array}{l}\text { Crop Field } \\
\text { Irrigation }\end{array}$ & $\begin{array}{l}\text { Sensors for data } \\
\text { collection, IOT } \\
\text { Hardware } \\
\text { Implementation }\end{array}$ & $\begin{array}{l}\text { This system needs minimal maintenance and } \\
\text { the power consumption is also greatly reduced. } \\
\text { Increased efficiency and economic feasibility } \\
\text { are obtained. }\end{array}$ & $\begin{array}{l}\text { Prediction system can be } \\
\text { developed with the help of } \\
\text { the data obtained using } \\
\text { sensors, where Artificial } \\
\text { Intelligence can be employed. }\end{array}$ \\
\hline 10 & Kamienski et al. (2019) & Precision Irrigation & $\begin{array}{l}\text { Internet of Things, } \\
\text { Smart Systems }\end{array}$ & $\begin{array}{l}\text { Performance analysis of key FIWARE } \\
\text { components personalized for each SWAMP } \\
\text { pilot scenario was analyzed to understand the } \\
\text { scalability limits of the system. }\end{array}$ & $\begin{array}{l}\text { The platform deployment } \\
\text { scenarios along with } \\
\text { irrigation models can be } \\
\text { improved further for more } \\
\text { advanced performance analysis. }\end{array}$ \\
\hline 11 & Goap et al. (2018) & $\begin{array}{l}\text { Smart irrigation } \\
\text { management system }\end{array}$ & $\begin{array}{l}\text { Machine Learning, } \\
\text { Internet of Things }\end{array}$ & $\begin{array}{l}\text { Soil-moisture prediction is done by Machine } \\
\text { Learning techniques therefore improved accuracy } \\
\text { and less error is observed. Helps in effective } \\
\text { irrigation decisions with optimum water usage. }\end{array}$ & $\begin{array}{l}\text { Water saving analysis can be } \\
\text { done with multiple nodes } \\
\text { along with minimizing the } \\
\text { system cost. }\end{array}$ \\
\hline
\end{tabular}




\begin{tabular}{|c|c|c|c|c|c|}
\hline 12 & Severino et al. (2018) & Irrigation Scheduling & $\begin{array}{l}\text { Remote Sensing, } \\
\text { Internet of Things, } \\
\text { Wireless Sensor } \\
\text { Networks }\end{array}$ & $\begin{array}{l}\text { Best management practices to the farming } \\
\text { community and public decision makers. }\end{array}$ & $\begin{array}{l}\text { Some techniques can be used } \\
\text { assess and control the } \\
\text { environmental risks } \\
\text { associated with the use of } \\
\text { recycled water for irrigation. }\end{array}$ \\
\hline 13 & Nawandar et al. (2019) & $\begin{array}{l}\text { Crop Monitoring } \\
\text { and Automated } \\
\text { Irrigation System }\end{array}$ & $\begin{array}{l}\text { Internet of Things, } \\
\text { Neural Networks }\end{array}$ & $\begin{array}{l}\text { User Interaction and estimation of irrigation } \\
\text { scheduling, along with remote data monitoring. }\end{array}$ & $\begin{array}{l}\text { More effective utilization of water } \\
\text { and water saving can be done by } \\
\text { integrating computational } \\
\text { optimization Techniques. }\end{array}$ \\
\hline 14 & Bannerjee et al. (2018) & $\begin{array}{l}\text { Soil and Weed } \\
\text { Management }\end{array}$ & $\begin{array}{l}\text { Artificial Intelligence, } \\
\text { Internet of Things, Robotics }\end{array}$ & $\begin{array}{l}\text { Highlights of an already prosperous development } \\
\text { and a promising prospect of application } \\
\text { in Agriculture. }\end{array}$ & $\begin{array}{l}\text { Applications of hybrid } \\
\text { technologies can be observed } \\
\text { for better understanding. }\end{array}$ \\
\hline 15 & Arakeri et al. (2017) & Weed Control & $\begin{array}{l}\text { Robotics, Image } \\
\text { Processing, Machine } \\
\text { Learning, Internet of Things }\end{array}$ & $\begin{array}{l}\text { It is a portable wireless system capable to } \\
\text { identify weeds and selectively spray right } \\
\text { amount of the herbicide. }\end{array}$ & $\begin{array}{l}\text { Remote distance monitoring } \\
\text { can be employed along with } \\
\text { UAV. }\end{array}$ \\
\hline 16 & Panpatte et al. (2018) & $\begin{array}{l}\text { Soil management, } \\
\text { Crop management, } \\
\text { Weed management } \\
\text { and Disease } \\
\text { management }\end{array}$ & $\begin{array}{l}\text { Artificial Intelligence, } \\
\text { Internet of Things }\end{array}$ & $\begin{array}{l}\text { A special focus is laid on the strength and } \\
\text { limitations of the application and the way in } \\
\text { utilizing expert systems for higher productivity. }\end{array}$ & $\begin{array}{l}\text { AI in agriculture offers } \\
\text { flexibility, high } \\
\text { performance, accuracy and } \\
\text { cost-effectiveness. }\end{array}$ \\
\hline 17 & Lottes et al. (2018) & $\begin{array}{l}\text { Crop and Weed } \\
\text { Detection }\end{array}$ & $\begin{array}{l}\text { Deep Learning, } \\
\text { Robotics, Automation }\end{array}$ & $\begin{array}{l}\text { A novel crop-weed classification system has } \\
\text { been proposed. It is based on a fully convolutional } \\
\text { network with an encoder-decoder structure and } \\
\text { incorporates spatial information by considering } \\
\text { image sequences. }\end{array}$ & $\begin{array}{l}\text { The accuracy of crop weed } \\
\text { classification can be } \\
\text { improves further by } \\
\text { bioinspired algorithms. }\end{array}$ \\
\hline 18 & Jha et al. (2019) & $\begin{array}{l}\text { Automation in } \\
\text { Agriculture }\end{array}$ & $\begin{array}{l}\text { IOT, Wireless } \\
\text { Communications, Machine } \\
\text { learning and Artificial } \\
\text { Intelligence, Deep learning }\end{array}$ & $\begin{array}{l}\text { A system which can be implemented in botanical } \\
\text { farm for flower and leaf identification and watering } \\
\text { using IOT. }\end{array}$ & $\begin{array}{l}\text { Thermal Imaging can also be } \\
\text { implemented by using } \\
\text { drones and thermal camera in it. }\end{array}$ \\
\hline 19 & $\begin{array}{l}\text { Bashir and } \\
\text { Sharma (2012) }\end{array}$ & $\begin{array}{l}\text { Plant Disease } \\
\text { Detection }\end{array}$ & Image Processing & $\begin{array}{l}\text { Classification of various kinds of plant diseases } \\
\text { is done using texture and color analysis. A Bayes } \\
\text { classifiers used to classify various plant diseases } \\
\text { working upon the resultant images. }\end{array}$ & $\begin{array}{l}\text { Bayes, K-means clustering } \\
\text { and principal component } \\
\text { classifier can be analyzed } \\
\text { further for classification } \\
\text { purpose. }\end{array}$ \\
\hline 20 & & $\begin{array}{l}\text { Leaf Disease } \\
\text { Detection of } \\
\text { Cotton Plant }\end{array}$ & Image Processing & $\begin{array}{l}\text { This system effectively detects diseased spots } \\
\text { present and classifies type of disease being affected } \\
\text { using Euclidian classifier based on the features } \\
\text { extracted from the diseased portion using GLCM matrix. }\end{array}$ & $\begin{array}{l}\text { Treatment measures are } \\
\text { provided to control the } \\
\text { disease. }\end{array}$ \\
\hline 21 & $\begin{array}{l}\text { Singh and } \\
\text { Misra (2017) }\end{array}$ & $\begin{array}{l}\text { Plant Leaf Disease } \\
\text { Detection }\end{array}$ & $\begin{array}{l}\text { Image Processing, } \\
\text { Genetic Algorithm }\end{array}$ & $\begin{array}{l}\text { Image segmentation is an important aspect for disease } \\
\text { detection in plant leaf disease, which is done by using } \\
\text { genetic algorithm. Banana, beans, jackfruit, lemon, } \\
\text { mango, potato, tomato and sapota are some of } \\
\text { those ten species on which proposed algorithm } \\
\text { can also be used. }\end{array}$ & $\begin{array}{l}\text { To improve recognition rate } \\
\text { in classification process } \\
\text { Artificial Neural Network, } \\
\text { Bayes classifier, Fuzzy } \\
\text { Logic and hybrid algorithms }\end{array}$ \\
\hline 22 & Schor et al. (2016) & $\begin{array}{l}\text { Disease Detection } \\
\text { in Green House }\end{array}$ & $\begin{array}{l}\text { Robotics and } \\
\text { Automation }\end{array}$ & $\begin{array}{l}\text { This system improves disease control, increase } \\
\text { yield and reduce pesticide application. }\end{array}$ & $\begin{array}{l}\text { Soft computing techniques } \\
\text { can be integrated to further } \\
\text { increase efficiency and } \\
\text { effectivity of system. }\end{array}$ \\
\hline 23 & Lee et al. (2017) & $\begin{array}{l}\text { Disease and } \\
\text { Pest Prediction } \\
\text { in Orchard }\end{array}$ & Internet of Things & $\begin{array}{l}\text { To reduce the frequent use of insecticides and } \\
\text { fungicides and to predict when the pests appear. }\end{array}$ & $\begin{array}{l}\text { Machine Learning } \\
\text { Techniques can be employed } \\
\text { for accurate prediction. }\end{array}$ \\
\hline 24 & Khattab et al. (2019) & $\begin{array}{l}\text { Early Plant } \\
\text { Disease Forecast }\end{array}$ & $\begin{array}{l}\text { Internet of Things, } \\
\text { Convolution Neural } \\
\text { Networks, Wireless } \\
\text { Sensor Networks }\end{array}$ & $\begin{array}{l}\text { Proposed model is capable to reduce the density } \\
\text { of the camera layout and reduce cost of } \\
\text { infrastructure. }\end{array}$ & $\begin{array}{l}\text { To improve the model } \\
\text { against images with motion } \\
\text { blur or noise. }\end{array}$ \\
\hline 25 & Zhao et al. (2020) & $\begin{array}{l}\text { Crop Disease } \\
\text { Recognition }\end{array}$ & $\begin{array}{l}\text { Convolution Neural } \\
\text { Network, Internet } \\
\text { of Things }\end{array}$ & $\begin{array}{l}\text { A deep fully connected network is proposed } \\
\text { to fuse visual features as well as contextual } \\
\text { features and output the crop disease prediction. }\end{array}$ & $\begin{array}{l}\text { Disease prediction at early } \\
\text { stage can be efficiently done } \\
\text { by integrating sensors and cameras. }\end{array}$ \\
\hline 26 & Kim et al. (2018) & $\begin{array}{l}\text { Strawberry Disease } \\
\text { Prediction System }\end{array}$ & $\begin{array}{l}\text { Internet of Things, } \\
\text { Smart Farming }\end{array}$ & $\begin{array}{l}\text { The developed system was verified through } \\
\text { design and analysis of a strawberry infection } \\
\text { prediction system. It was also compared with } \\
\text { other infection models. }\end{array}$ & $\begin{array}{l}\text { The developed system can } \\
\text { be linked to the NCPMS to } \\
\text { provide information on } \\
\text { infection risk like crop risk, } \\
\text { mycelial growth rate, disease } \\
\text { development rate, } \\
\text { germination rate etc. }\end{array}$ \\
\hline 27 & Pantazi et al. (2019) & $\begin{array}{l}\text { Leaf Disease } \\
\text { Detection in } \\
\text { Different Crop } \\
\text { Species }\end{array}$ & $\begin{array}{l}\text { Machine Learning, } \\
\text { Computer Vision }\end{array}$ & $\begin{array}{l}\text { The algorithms trained on vine leaves have been } \\
\text { tested on various crops which achieve high } \\
\text { generalization behavior. Success rate of } 95 \% \text { is } \\
\text { achieved for the total } 46 \text { plant condition. }\end{array}$ & $\begin{array}{l}\text { The detection of health plant } \\
\text { condition can be tested by a } \\
\text { combination of more than } \\
\text { one Class Classifiers. }\end{array}$ \\
\hline 28 & Ahirwar et al. (2019) & $\begin{array}{l}\text { Drones in } \\
\text { Agriculture }\end{array}$ & $\begin{array}{l}\text { Drone, Automation, } \\
\text { Internet of Things }\end{array}$ & $\begin{array}{l}\text { The Use of Drone in agriculture offer major } \\
\text { applications in agriculture like irrigation, crop } \\
\text { monitoring, soil and field analysis and bird control. }\end{array}$ & $\begin{array}{l}\text { Advanced IoT sensors and } \\
\text { modern cameras can be used } \\
\text { for effective monitoring. }\end{array}$ \\
\hline 29 & Elijah et al. (2018) & $\begin{array}{l}\text { Data analytics } \\
\text { in agriculture }\end{array}$ & $\begin{array}{l}\text { Internet of Things, } \\
\text { Data Analytics, } \\
\text { Smart Systems }\end{array}$ & $\begin{array}{l}\text { Benefits and challenges have been identified. } \\
\text { The combination of IoT and DA is enabling smart } \\
\text { agriculture. }\end{array}$ & $\begin{array}{l}\text { Future trends and } \\
\text { opportunities in the category } \\
\text { of technological innovations, } \\
\text { application scenarios, } \\
\text { business and marketability. }\end{array}$ \\
\hline 30 & Muminov et al. (2019) & $\begin{array}{l}\text { Modern virtual } \\
\text { fencing application }\end{array}$ & $\begin{array}{l}\text { Internet of Things, } \\
\text { Machine Learning, } \\
\text { Support Vector Machines }\end{array}$ & $\begin{array}{l}\text { The classification performance of goat behavior } \\
\text { classes like grazing, walking, running, standing } \\
\text { and lying, were reported. }\end{array}$ & $\begin{array}{l}\text { Some new functions must be } \\
\text { developed using developed } \\
\text { SVM classification, which } \\
\text { give more accurate information } \\
\text { about the health of animals. }\end{array}$ \\
\hline 31 & Lavanya et al. (2020) & $\begin{array}{l}\text { Fertilizer Intimation } \\
\text { System }\end{array}$ & $\begin{array}{l}\text { Internet of Things, } \\
\text { Sensor Networks, }\end{array}$ & $\begin{array}{l}\text { A sensor network scenario is created to analyze } \\
\text { the performance of designed NPK sensor in terms }\end{array}$ & $\begin{array}{l}\text { SMS facility for farmers to increase } \\
\text { the yielding of crops for adding the }\end{array}$ \\
\hline
\end{tabular}




\begin{tabular}{|c|c|c|c|c|c|}
\hline & & & Fuzzy Systems & $\begin{array}{l}\text { of throughput, end to end delay and jitter using } \\
\text { Qualnet simulator. Developed IoT system is found } \\
\text { more helpful for high yielding of crops. }\end{array}$ & $\begin{array}{l}\text { appropriate fertilizer at the } \\
\text { right time depending upon } \\
\text { the nutrients level. }\end{array}$ \\
\hline 32 & Faiçal et al. (2014) & Spraying Pesticides & $\begin{array}{l}\text { Wireless Sensor } \\
\text { Networks, Unmanned } \\
\text { Aerial Vehicles }\end{array}$ & $\begin{array}{l}\text { The UAV route is adjusted according to changes } \\
\text { in wind intensity and direction. The algorithm is } \\
\text { adaptive and Wireless Sensor Network (WSN) } \\
\text { deployed in the crop field provides data. }\end{array}$ & $\begin{array}{l}\text { UAV path optimization can } \\
\text { be done by metaheuristic } \\
\text { techniques for efficient } \\
\text { operation. }\end{array}$ \\
\hline 33 & Naganur et al. (2012) & Fruits Sorting & Fuzzy Logic & $\begin{array}{l}\text { Image processing techniques are used to classify } \\
\text { and grade fruits. Fruit's image is captured with } \\
\text { digital camera, where feature extraction, } \\
\text { classification and grading are done based on } \\
\text { color and size. }\end{array}$ & $\begin{array}{l}\text { There are some fruits with } \\
\text { same color and size, hence } \\
\text { one more feature, namely } \\
\text { texture need to be considered } \\
\text { for classification of such fruits. }\end{array}$ \\
\hline 34 & Lin et al. (2020a) & Fruit detection & $\begin{array}{l}\text { Image Processing, } \\
\text { Machine Learning }\end{array}$ & $\begin{array}{l}\text { PSM and PHT based algorithms were developed } \\
\text { for detecting most type of fruits, such as green, } \\
\text { orange, circular and non-circular, in natural } \\
\text { environments. }\end{array}$ & $\begin{array}{l}\text { A scale-invariant PHT can } \\
\text { be established. Some } \\
\text { optimization algorithms can } \\
\text { also be employed. }\end{array}$ \\
\hline 35 & Bac et al. (2013) & $\begin{array}{l}\text { Harvesting of } \\
\text { sweet-pepper }\end{array}$ & $\begin{array}{l}\text { Robotics, Image } \\
\text { processing }\end{array}$ & $\begin{array}{l}\text { A robust and balanced accuracy performance } \\
\text { measure Rob was introduced for CART } \\
\text { pruning and feature selection. }\end{array}$ & $\begin{array}{l}\text { Multiple feature extraction } \\
\text { techniques can be compared. }\end{array}$ \\
\hline 36 & Barnett et al. (2020) & Kiwifruit Harvesting & Sensor Network, Robotics & $\begin{array}{l}\text { An approach was developed for uniform work } \\
\text { distribution even when the fruits do not distribute } \\
\text { uniformly across the canopy. }\end{array}$ & $\begin{array}{l}\text { Task completion time can } \\
\text { further be minimized with } \\
\text { increased accuracy. }\end{array}$ \\
\hline 37 & Lin et al. (2020b) & Fruit Detection & $\begin{array}{l}\text { Image Processing, } \\
\text { Support Vector } \\
\text { Machine }\end{array}$ & $\begin{array}{l}\text { An angle/color/shape based Global Point Cloud } \\
\text { Descriptor (GPCD) is developed to extract a feature } \\
\text { vector for an entire point cloud and a support } \\
\text { vector machine classifier trained on the GPCD } \\
\text { features is used to exclude false positives. }\end{array}$ & $\begin{array}{l}\text { Color and shape of some leaf } \\
\text { or branch may resemble with } \\
\text { fruits so future work will } \\
\text { focus on integrating other } \\
\text { features, like texture in } \\
\text { GPCD and on improving the } \\
\text { overall real-time performance. }\end{array}$ \\
\hline 38 & $\begin{array}{l}\text { Wan and } \\
\text { Goudos (2020) }\end{array}$ & $\begin{array}{l}\text { Multiclass } \\
\text { Fruit Detection }\end{array}$ & $\begin{array}{l}\text { Deep Learning, } \\
\text { Image Recognition }\end{array}$ & $\begin{array}{l}\text { Deep learning framework is discussed for multi-class } \\
\text { fruits detection based on improved Faster R-CNN. }\end{array}$ & $\begin{array}{l}\text { Higher detecting accuracy } \\
\text { and lower processing time } \\
\text { can further be obtained by an } \\
\text { autonomous and real-time } \\
\text { harvesting system. }\end{array}$ \\
\hline 39 & Leng et al. (2019) & $\begin{array}{l}\text { Supply Chain } \\
\text { Inspection System }\end{array}$ & $\begin{array}{l}\text { RFID Technology, } \\
\text { Internet of Things }\end{array}$ & $\begin{array}{l}\text { RFID technology is combined with supply chain } \\
\text { detection, analyses the application of RFID } \\
\text { technology in the detection of agricultural product } \\
\text { supply chain and designs the system based } \\
\text { on RFID in the supply chain. }\end{array}$ & $\begin{array}{l}\text { RFID technology can be } \\
\text { integrated with Soft } \\
\text { Computing to promote the } \\
\text { efficiency of agricultural } \\
\text { supply chain management. }\end{array}$ \\
\hline 40 & Caro et al. (2018) & $\begin{array}{l}\text { Traceability in } \\
\text { Agri food Supply } \\
\text { Chain Management }\end{array}$ & $\begin{array}{l}\text { Internet of Things, } \\
\text { Blockchain } \\
\text { Technology }\end{array}$ & $\begin{array}{l}\text { Few use cases were developed and deployed to } \\
\text { achieve traceability using two different blockchain } \\
\text { implementations: Ethereum and Hyperledger Sawtooth. }\end{array}$ & $\begin{array}{l}\text { Performance can further be } \\
\text { improved in terms of } \\
\text { latency, CPU and network usage. }\end{array}$ \\
\hline 41 & $\begin{array}{l}\text { Wang and } \\
\text { Yue (2017) }\end{array}$ & $\begin{array}{l}\text { Food Supply } \\
\text { Chain }\end{array}$ & $\begin{array}{l}\text { Internet of Things, } \\
\text { Supply Chain } \\
\text { Management }\end{array}$ & $\begin{array}{l}\text { Food safety pre-warning system reduced the cost } \\
\text { related food safety and quality. It can also } \\
\text { enhance the sustainability of food supply chain. }\end{array}$ & $\begin{array}{l}\text { Smart Prewiring system can } \\
\text { effectively identify safety } \\
\text { risks and accurately } \\
\text { determine whether a } \\
\text { warning should be issued. } \\
\text { SMS facility can also be included. }\end{array}$ \\
\hline
\end{tabular}

\section{Conclusion}

Artificial Intelligence (AI) and Internet of Things (IoT) are very supportive to farmers to alter traditional way of farming into smart farming in growing population scenario. In conventional farming process, large number of human labors are required to carry out every task like nursing soil, monitoring crop, spraying pesticides and herbicides, weed handling, irrigation and harvesting. Smart agriculture is meant for precise farming, better crop quality and quantity by optimizing agricultural resources via latest innovations. In this study authors have set the efforts to summarized literature review from quality research papers in orderly manner, available on modern technologies like AI, ML, IoT, Wireless Sensor Networks etc. Industries are working very hard for intelligent agricultural technological development through Robot, Drones, Unmanned Aerial Vehicles, machine automation etc. to improve efficiency and productivity. In fact, Worldwide Government is also supporting research in the domain of agriculture by making some policies, funding agencies, rebate or allowance in investments, loan available. This study is an attempt to give a thought of mechanization in agriculture. Analysis of agricultural applications using Artificial Intelligence and Internet of Things has been presented.

\section{Acknowledgement}

The authors are grateful to ABES Institute of Technology, Ghaziabad, India and Jizan University, Saudi Arabia for the permission to publish this research.

\section{Author's Contributions}

All authors equally contributed in this work.

\section{Ethics}

This paper reflects the authors' own study and examination in a truthful and complete means. The paper is not currently being considered for publication elsewhere. 


\section{References}

Ahirwar, S., Swarnkar, R., Bhukya, S., \& Namwade, G. (2019). Application of drone in agriculture. International Journal of Current Microbiology and Applied Sciences, 8(01), 2500-2505. doi.org/10.20546/ijcmas.2019.801.264

Ahmed, N., De, D., \& Hussain, I. (2018). Internet of Things (IoT) for smart precision agriculture and farming in rural areas. IEEE Internet of Things Journal, 5(6), 4890-4899.

https://ieeexplore.ieee.org/abstract/document/8521668/

Angelopoulos, C. M., Filios, G., Nikoletseas, S., \& Raptis, T. P. (2020). Keeping data at the edge of smart irrigation networks: A case study in strawberry greenhouses. Computer Networks, 167, 107039. doi.org/10.1016/j.comnet.2019.107039

Arakeri, M. P., Kumar, B. V., Barsaiya, S., \& Sairam, H. V. (2017, September). Computer vision based robotic weed control system for precision agriculture. In 2017 International Conference on Advances in Computing, Communications and Informatics (ICACCI) (pp. 1201-1205). IEEE. doi.org/10.1109/ICACCI.2017.8126005

Bac, C. W., Hemming, J., \& Van Henten, E. J. (2013). Robust pixel-based classification of obstacles for robotic harvesting of sweet-pepper. Computers and electronics in agriculture, 96, 148-162. doi.org/10.1016/j.compag.2013.05.004

Bannerjee, G., Sarkar, U., Das, S., \& Ghosh, I. (2018). Artificial intelligence in agriculture: A literature survey. International Journal of Scientific Research in Computer Science Applications and Management Studies, 7(3), 1-6.

Barnett, J., Duke, M., Au, C. K., \& Lim, S. H. (2020). Work distribution of multiple Cartesian robot arms for kiwifruit harvesting. Computers and Electronics in Agriculture, 169, 105202. doi.org/10.1016/j.compag.2019.105202

Bashir, S., \& Sharma, N. (2012). Remote area plant disease detection using image processing. IOSR Journal of Electronics and Communication Engineering, 2(6), 31-34.

Cambra Baseca, C., Sendra, S., Lloret, J., \& Tomas, J. (2019). A smart decision system for digital farming. Agronomy, 9(5), 216. doi.org/10.3390/agronomy9050216

Caro, M. P., Ali, M. S., Vecchio, M., \& Giaffreda, R. (2018, May). Blockchain-based traceability in Agri-Food supply chain management: A practical implementation. In 2018 IoT Vertical and Topical Summit on Agriculture-Tuscany (IOT Tuscany) (pp. 1-4). IEEE. doi.org/10.1109/IOT-TUSCANY.2018.8373021

Elijah, O., Rahman, T. A., Orikumhi, I., Leow, C. Y., \& Hindia, M. N. (2018). An overview of Internet of Things (IoT) and data analytics in agriculture: Benefits and challenges. IEEE Internet of Things Journal, 5(5), 3758-3773.
Faiçal, B. S., Costa, F. G., Pessin, G., Ueyama, J., Freitas, H., Colombo, A., ... \& Braun, T. (2014). The use of unmanned aerial vehicles and wireless sensor networks for spraying pesticides. Journal of Systems Architecture, 60(4), 393-404. doi.org/10.1016/j.sysarc.2014.01.004

Furukawa, F., Maruyama, K., Saito, Y. K., \& Kaneko, M. (2020). Corn height estimation using UAV for yield prediction and crop monitoring. In Unmanned Aerial Vehicle: Applications in Agriculture and Environment (pp. 51-69). Springer, Cham. doi.org/10.1007/978-3-030-27157-2_5

Goap, A., Sharma, D., Shukla, A. K., \& Krishna, C. R. (2018). An IoT based smart irrigation management system using Machine learning and open source technologies. Computers and electronics in agriculture, 155, 41-49. doi.org/10.1016/j.compag.2018.09.040

Gondchawar, N., \& Kawitkar, R. S. (2016). IoT based smart agriculture. International Journal of advanced research in Computer and Communication Engineering, 5(6), 838-842.

Harun, A. N., Mohamed, N., Ahmad, R., \& Ani, N. N. (2019). Improved Internet of Things (IoT) monitoring system for growth optimization of Brassica chinensis. Computers and Electronics in Agriculture, 164, 104836. doi.org/10.1016/j.compag.2019.05.045

Hirsch, C., Bartocci, E., \& Grosu, R. (2019, June). Capacitive soil moisture sensor node for IoT in agriculture and home. In 2019 IEEE 23rd International Symposium on Consumer Technologies (ISCT) (pp. 97-102). IEEE. doi.org/10.1109/ISCE.2019.8901012

Jha, K., Doshi, A., Patel, P., \& Shah, M. (2019). A comprehensive review on automation in agriculture using artificial intelligence. Artificial Intelligence in Agriculture, 2, 1-12. doi.org/10.1016/j.aiia.2019.05.004

Kale, A. P., \& Sonavane, S. P. (2019). IoT based Smart Farming: Feature subset selection for optimized highdimensional data using improved GA based approach for ELM. Computers and Electronics in Agriculture, 161, 225-232. doi.org/10.1016/j.compag.2018.04.027

Kamienski, C., Soininen, J. P., Taumberger, M., Dantas, R., Toscano, A., Salmon Cinotti, T., ... \& Torre Neto, A. (2019). Smart water management platform: IoTbased precision irrigation for agriculture. Sensors, 19(2), 276. doi.org/10.3390/s19020276

Keswani, B., Mohapatra, A. G., Mohanty, A., Khanna, A., Rodrigues, J. J., Gupta, D., \& De Albuquerque, V. H. C. (2019). Adapting weather conditions based IoT enabled smart irrigation technique in precision agriculture mechanisms. Neural Computing and Applications, 31(1), 277-292. doi.org/10.1007/s00521-018-3737-1

Khanna, A., \& Kaur, S. (2019). Evolution of Internet of Things (IoT) and its significant impact in the field of Precision Agriculture. Computers and electronics in agriculture, 157, 218-231. doi.org/10.1016/j.compag.2018.12.039 
Khattab, A., Habib, S. E., Ismail, H., Zayan, S., Fahmy, Y., \& Khairy, M. M. (2019). An IoT-based cognitive monitoring system for early plant disease forecast. Computers and Electronics in Agriculture, 166, 105028. doi.org/10.1016/j.compag.2019.105028

Kim, S., Lee, M., \& Shin, C. (2018). IoT-based strawberry disease prediction system for smart farming. Sensors, 18(11), 4051. doi.org/10.3390/s18114051

Kim, Y., Evans, R. G., \& Iversen, W. M. (2008). Remote sensing and control of an irrigation system using a distributed wireless sensor network. IEEE transactions on instrumentation and measurement, 57(7), 1379-1387. doi.org/10.1109/TIM.2008.917198

Kumar, A., \& Hancke, G. P. (2014). A zigbee-based animal health monitoring system. IEEE sensors Journal, 15(1), 610-617. doi.org/10.1109/JSEN.2014.2349073

Kurihara, J., Ishida, T., \& Takahashi, Y. (2020). Unmanned Aerial Vehicle (UAV)-based hyperspectral imaging system for precision agriculture and forest management. In Unmanned Aerial Vehicle: Applications in Agriculture and Environment (pp. 25-38). Springer, Cham. doi.org/10.1007/978-3-030-27157-2_3

Lai, X., Yang, T., Wang, Z., \& Chen, P. (2019). IoT implementation of Kalman filter to improve accuracy of air quality monitoring and prediction. Applied Sciences, 9(9), 1831. https://www.mdpi.com/20763417/9/9/1831

Lavanya, G., Rani, C., \& Ganesh Kumar, P. (2020). An automated low cost IoT based Fertilizer Intimation System for smart agriculture. Sustainable Computing: Informatics and Systems, 28, 100300. doi.org/10.1016/j.suscom.2019.01.002

Lazarescu, M. T. (2013). Design of a WSN platform for long-term environmental monitoring for IoT applications. IEEE Journal on emerging and selected topics in circuits and systems, 3(1), 45-54. doi.org/10.1109/JETCAS.2013.2243032

Lee, H., Moon, A., Moon, K., \& Lee, Y. (2017, July). Disease and pest prediction IoT system in orchard: A preliminary study. In 2017 Ninth International Conference on Ubiquitous and Future Networks (ICUFN) (pp. 525-527). IEEE. doi.org/10.1109/ICUFN.2017.7993840

Leng, K., Jin, L., Shi, W., \& Van Nieuwenhuyse, I. (2019). Research on agricultural products supply chain inspection system based on internet of things. Cluster Computing, 22(4), 8919-8927. doi.org/10.1007/s10586-018-2021-6

Lin, G., Tang, Y., Zou, X., Cheng, J., \& Xiong, J. (2020a). Fruit detection in natural environment using partial shape matching and probabilistic Hough transform. Precision Agriculture, 21(1), 160-177. doi.org/10.1007/s11119-019-09662-w
Lin, G., Tang, Y., Zou, X., Xiong, J., \& Fang, Y. (2020b). Color-, depth- and shape-based 3D fruit detection. Precision Agriculture, 21(1), 1-17. doi.org/10.1007/s11119-019-09654-w

Liu, S., Guo, L., Webb, H., Ya, X., \& Chang, X. (2019). Internet of Things monitoring system of modern ecoagriculture based on cloud computing. IEEE Access, 7, 37050-37058. doi.org/10.1109/ACCESS.2019.2903720

Lottes, P., Behley, J., Milioto, A., \& Stachniss, C. (2018). Fully convolutional networks with sequential information for robust crop and weed detection in precision farming. IEEE Robotics and Automation Letters, 3(4), 2870-2877. doi.org/10.1109/LRA.2018.2846289

Morais, R., Silva, N., Mendes, J., Adão, T., Pádua, L., LópezRiquelme, J. A., ... \& Peres, E. (2019). Mysense: A comprehensive data management environment to improve precision agriculture practices. Computers and Electronics in Agriculture, 162, 882-894. doi.org/10.1016/j.compag.2019.05.028

Mulla, D. J. (2013). Twenty five years of remote sensing in precision agriculture: Key advances and remaining knowledge gaps. Biosystems engineering, 114(4), 358-371. doi.org/10.1016/j.biosystemseng.2012.08.009

Muminov, A., Na, D., Lee, C., Kang, H. K., \& Jeon, H. S. (2019). Modern virtual fencing application: Monitoring and controlling behavior of goats using GPS collars and warning signals. Sensors, 19(7), 1598. doi.org/10.3390/s19071598

Naganur, H. G., Sannakki, S. S., Rajpurohit, V. S., \& Arunkumar, R. (2012). Fruits sorting and grading using fuzzy logic. Int $\mathrm{J}$ Adv Res Comput Eng Technol, 1(6), 117-122.

Nawandar, N. K., \& Satpute, V. R. (2019). IoT based low cost and intelligent module for smart irrigation system. Computers and electronics in agriculture, 162, 979-990. doi.org/10.1016/j.compag.2019.05.027

Panpatte, D. G. (2018). Artificial intelligence in agriculture: An emerging era of research. Anand Agricultural University.

Pantazi, X. E., Moshou, D., \& Tamouridou, A. A. (2019). Automated leaf disease detection in different crop species through image features analysis and One Class Classifiers. Computers and electronics in agriculture, 156, 96-104. doi.org/10.1016/j.compag.2018.11.005

Park, D. H., \& Park, J. W. (2011). Wireless sensor network-based greenhouse environment monitoring and automatic control system for dew condensation prevention. Sensors, 11(4), 3640-3651. doi.org/10.3390/s110403640

Potamitis, I., Rigakis, I., Tatlas, N. A., \& Potirakis, S. (2019). In-vivo vibroacoustic surveillance of trees in the context of the IoT. Sensors, 19(6), 1366. doi.org/10.3390/s19061366 
Potena, C., Nardi, D., \& Pretto, A. (2016, July). Fast and accurate crop and weed identification with summarized train sets for precision agriculture. In International Conference on Intelligent Autonomous Systems (pp. 105-121). Springer, Cham. doi.org/10.1007/978-3-319-48036-7_9

Rajakumar, G., Kumar, T. A., Samuel, T. A., \& Kumaran, E. M. (2018). IoT based milk monitoring system for detection of milk adulteration. International Journal of Pure and Applied Mathematics, 118(9), 21-32. http://www.acadpubl.eu/jsi/2018-118-79/articles/9/4.pdf

Sahni, V., Srivastava, S., \& Khan, R. (2021). Modelling Techniques to Improve the Quality of Food Using Artificial Intelligence. Journal of Food Quality, 2021. doi.org/10.1155/2021/2140010

Savitha, M., \& UmaMaheswari, O. P. (2018). Smart crop field irrigation in IOT architecture using sensors. International Journal of Advanced Research in Computer Science, 9(1). doi.org/10.26483/ijarcs.v9i1.5348

Schor, N., Bechar, A., Ignat, T., Dombrovsky, A., Elad, Y., \& Berman, S. (2016). Robotic disease detection in greenhouses: Combined detection of powdery mildew and tomato spotted wilt virus. IEEE Robotics and Automation Letters, 1(1), 354-360. doi.org/10.1109/LRA.2016.2518214

Seem, A., Chauhan, A. K., \& Khan, R. (2022). Artificial Neural Network, Convolutional Neural Network Visualization and Image Security. In Soft Computing: Theories and Applications (pp. 623-632). Springer, Singapore. doi.org/10.1007/978-981-161740-9_51

Severino, G., D’Urso, G., Scarfato, M., \& Toraldo, G. (2018). The IoT as a tool to combine the scheduling of the irrigation with the geostatistics of the soils. Future Generation Computer Systems, 82, 268-273. doi.org/10.1016/j.future.2017.12.058

Singh, V., \& Misra, A. K. (2017). Detection of plant leaf diseases using image segmentation and soft computing techniques. Information processing in Agriculture, 4(1), 41-49. doi.org/10.1016/j.inpa.2016.10.005

Sun, Y., Ding, W., Shu, L., Huang, K., Li, K., Zhang, Y., \& Huo, Z. (2019, May). When mobile crowd sensing meets smart agriculture: Poster. In Proceedings of the ACM Turing Celebration Conference-China (pp. 1-2). doi.org/10.1145/3321408.3321611
Talaviya, T., Shah, D., Patel, N., Yagnik, H., \& Shah, M. (2020). Implementation of artificial intelligence in agriculture for optimisation of irrigation and application of pesticides and herbicides. Artificial Intelligence in Agriculture, 4, 58-73. doi.org/10.1016/j.aiia.2020.04.002

Triantafyllou, A., Sarigiannidis, P., \& Bibi, S. (2019). Precision agriculture: A remote sensing monitoring system architecture. Information, 10(11), 348. doi.org/10.3390/info10110348

Wan, S., \& Goudos, S. (2020). Faster R-CNN for multiclass fruit detection using a robotic vision system. Computer Networks, 168, 107036. doi.org/10.1016/j.comnet.2019.107036

Wang, J., \& Yue, H. (2017). Food safety pre-warning system based on data mining for a sustainable food supply chain. Food Control, 73, 223-229. doi.org/10.1016/j.foodcont.2016.09.048

Yaqub, U., Al-Nasser, A., \& Sheltami, T. (2019). Implementation of a hybrid wind-solar desalination plant from an internet of things (IoT) perspective on a network simulation tool. Applied computing and informatics, 15(1), 7-11. doi.org/10.1016/j.aci.2018.03.001

Yue, Y., Cheng, X., Zhang, D., Wu, Y., Zhao, Y., Chen, Y., ... \& Zhang, Y. (2018). Deep recursive super resolution network with Laplacian Pyramid for better agricultural pest surveillance and detection. Computers and electronics in agriculture, 150, 26-32. doi.org/10.1016/j.compag.2018.04.004

Zadokar, A. R., Bhagat, D. P., Nayase, A. A., \& Mhaske, S. S. (2017). Leaf disease detection of cotton plant using image processing techniques: a review. International Journal of Electronics, Communication and Soft Computing Science \& Engineering (IJECSCSE), 53-55.

https://search.proquest.com/openview/d953f5431b8 $75908546089 \mathrm{bc} 37 \mathrm{f} 1 \mathrm{~d} 60 \mathrm{c} / 1$ ?pq-

origsite $=$ gscholar $\& \mathrm{cbl}=2029261$

Zhao, Y., Liu, L., Xie, C., Wang, R., Wang, F., Bu, Y., \& Zhang, S. (2020). An effective automatic system deployed in agricultural Internet of Things using Multi-Context Fusion Network towards crop disease recognition in the wild. Applied Soft Computing, 89, 106128. doi.org/10.1016/j.asoc.2020.106128 